\title{
A Study of Mutagenic Variability on Seed Protein Content in Chickpea (Cicer arietinum L.).
}

\author{
Navnath G. Kashid ${ }^{1}$, Subhash B. More ${ }^{2}$ \\ ${ }^{1}$ Department of Botany, Vasant Mahavidyalaya Kaij, Dist: Beed. Maharashtra. India. 431123 \\ ${ }^{2}$ Department of Biology, Champawati College Beed. Maharashtra. India. 431122
}

\begin{abstract}
Biochemical analysis of 11 different chickpea germplasm, viable mutants and about 200 micro mutants was carried out for knowing the soluble seed protein content. The data regarding soluble seed protein content revealed substantial variability in all the germplasm lines and also different viable and micro mutants of both the cultivars of chickpea. Among 11 germplasm lines, the highest values for soluble seed protein content were recorded in chaffa and BG-256. The viable mutants in both the cultivars showed the variability in soluble seed protein content. In BDN 9-3, the highest value was observed in large leaf mutant while in PG-5, the late maturing mutant indicated highest value for soluble seed content. Thus, from the above observation, it can be said that mutagenic treatments tried in the present study have very much succeeded including genetic variability with significance alterations in growth and metabolism of the plant body. The result obtained decisively demonstrated the effective potential of the induced mutational approach in the genetic improvement of chickpea and recovering superior mutant types to helps obtain better desirable traits.
\end{abstract}

Keywords: seed protein, mutagenic variability, chickpea

\section{Introduction}

In chickpea (Cicer arietinum L.), genus Cicer belongs to the family Fabaceae. The genus Cicer consists of 44 species, including 35 perennial and eight annual wild species and one the domesticated chickpea, Cicer arietinum L. Chickpea seeds are very rich source of carbohydrates, proteins, fats and many other essential nutritive components which are consumed by humans. In fact, chickpea has one of the highest nutritional compositions of any dry edible legume and does not contain any specific major antinutritional factors and could be a useful source of dietary nutrients, especially in malnourished population.

Mutation breeding technique may have a greater role in crops like chickpea especially in India where a large part of the natural variability has been eliminated in the process of adaptation to the stress of the environment. Since chemical mutagens have been proved to be more potent and efficient in inducing mutations than physical ones (Kharkwal, 1998 a,b), henceforth, they have become the method of choice for genetic studies and remain popular even with the advent of new technologies.

The effect of the mutagens on the protein contents and the nitrate reductase activity (NRA) has also been reported by Barshile et al. (2009) in Cicer arietinum. With an aim to improve the seed protein content coupled with high grain yield of cereals and legumes the genetic fortification through induced mutagenesis has been done in the past and in fact at the end of late 1960,s a voluminous international research programme was started by the I.A.E.A. in Vienna with this aim viz., to improve the seed protein quantity and quality of cereals and legumes by means of mutations (Gottschalk, 1986).

Gottschalk (1986) suggested that it is possible to analyze the seed proteins of mutants quantitatively and qualitatively, which had been selected with regard to other useful traits but not with regard to improved seed proteins. And in this way, it is possible to obtain genotypes with increased protein production per plant, but they do not represent "protein mutants", for example, the bold seeded mutants of Vigna mungo obtained by Singh (1996) with gamma rays treatment showed a slight increase in protein content over the control.

\section{Material and Methods}

The present study was undertaken to estimate the extent of induced genetic variability for ten quantitative traits in certain biochemical indices of the seed components induced by ethyl methane sulphonate $(0.05 \%, 0.10 \%$ and $0.15 \%)$ and sodium azide $(0.01 \%, 0.02 \%$ and $0.03 \%)$. In present study 11 chickpea germplasm lines and viable mutants were practiced for estimation of protein. These seed material of chickpea (Cicer arietinum L.) namely, BDN9-3 and PG-5 obtained from Agricultural Research Station Badnapur, Dist: Jalna (Maharashtra) and MPKV, Rahuri, Dist: A. Nagar (Maharashtra) India, respectively for mutagenic treatment. The different viable mutants were practiced for seed protein content estimation from M2 and M3 generations.

\section{Extraction and Estimation of Seed Protein}

Mature seeds were washed with water, dried and ground to make fine powder. The mature seed powder was defatted with hexane, air dried and stored at $4 \mathrm{C}$. seed protein from mature defatted seed powder were kept for extraction in 1:6 proportion of distilled water with $1 \%$ (PVP) polyvinyl polypyrrolidone , are allowed to stand overnight. Suspension was centrifuged at $12,000 \mathrm{rpm}$ at $4 \mathrm{c}$ for 20 minutes to remove the particulate matter and clear supernatant was used for further protein estimation by the Biurate method. The protein value was expressed as $\mathrm{mg} / \mathrm{gm}$ of defatted seed powder.

\section{Result}

During the present study, the soluble protein content was estimated according to Biuret method. The soluble seed 


\section{International Journal of Science and Research (IJSR) \\ ISSN (Online): 2319-7064 \\ Index Copernicus Value (2013): 6.14 | Impact Factor (2014): 5.611}

protein estimates were carried out for 11 chickpea germplasm lines and different mutants of both the cultivars of chickpea.

The data regarding seed protein content revealed substantial variability in all the chickpea germplasm lines and also in different mutants of both the cultivars of chickpea. Among all 11 chickpea germplasm lines, the highest values were observed in chaffa, BG-256 and ICC-506. While the lowest value could be observed in ICCV-2 and Anigeri-1-1.

The viable mutants in both the cultivars of chickpea showed the variability in seed protein content. In BDN 9-3, highest value for soluble seed protein was observed in large leaf mutant while the lowest was in Anthoseed mutants. In PG-5, the late maturing mutant indicated the highest value for seed protein content while Anthoseed and xantha showed the lowest values. Biochemical studies regarding soluble seed protein content were done in about 200 micromutants from whom data of 50 mutants of both cultivars of chickpea have been given. These micromutants showed reduction in soluble protein content in BDN 9-3 while in PG-5; they showed increase as well as decrease in soluble seed protein content.

\section{Discussion}

The relatively new aspects in applied mutagenesis are the quantitative and qualitative alteration of seed storage substance like protein and carbohydrates and specific other substances deposited in various organs of plants. Especially emphasis is directed to seed proteins because a part of deficiency leading to malnutrition and undernourishment is related to insufficient protein supply.

The present study show variation in the protein content of different germplasm and mutants of chickpea. There was an increase as well as decrease of protein content. Gottschalk and Muller (1970) proposed that improvement of protein content and compositions can be achieved by genetic manipulation, which Narahari and Bhatia (1975) suggested mutation breeding for improving the quality of proteins. The amount and composition of seed protein are widely influenced both by environmental and endogenous factors.

Several attempts have been made to induce variation for protein quality and quantity using macro and micromutations (Varughese and Swaminathan 1966, Siddiq et.al, 1970, Gottschalk and Muller 1970, Sjodin 1971, Dahiya 1973, Singh and Chtaurvedi 1980, Thakare et.al, 1981, Chary 1983, and Padmavati 1993). Increase in protein content of the mutants in accordance with the results obtained by Bhamburkar (1981), Jijiya (1986), Sudharani (1990) and Rayyan (1995).

There were negative correlation between yield and protein of seed instead of increase in protein content and some other like days to protein content and some other traits like day to maturity, number of grains and size and the grain yield.

Contrary reports have been put forward by several workers on the extent of success of induced mutations for high grain yield coupled with high protein contents of the mutants.
Some research works by Gottschalk and Muller (1982), Matta and Gatehouse (1982), Gottschalk and Wolff (1983a), are of the view that high protein content is difficult to combine with high yield as these two traits reveal almost negative correlation. However, high yielding mutants coupled with high protein contents were reported by Borah and Goswami (1995) in rice, Kalia et al. (2000) in wheat, Ignacimuthu and Babu (1989a) in urdbean, Naik et al. (2002) in mungbean.

Table 1: Soluble protein content in different viable chickpea germplasm

\begin{tabular}{|c|c|c|}
\hline Sr.No. & Germplasms & $\begin{array}{c}\text { Protein } \mathrm{mg} / \mathrm{gm} \text { of defatted } \\
\text { seed powder }\end{array}$ \\
\hline 1 & ICCV-2 & 52.8 \\
\hline 2 & Chaffa & 92 \\
\hline 3 & Vishal & 71.75 \\
\hline 4 & Annigeri $-1-1$ & 57.85 \\
\hline 5 & ICC-506 & 81.9 \\
\hline 6 & BG-256 & 92 \\
\hline 7 & RG-81-1-1 & 68 \\
\hline 8 & ICC-86102 & 69.6 \\
\hline 9 & Vijay & 79.05 \\
\hline 10 & BDN-9-3 & 67.65 \\
\hline 11 & PG-5 & 58.17 \\
\hline
\end{tabular}

Table 02: Soluble protein content in different viable mutants of chickpea. Variety. BDN-9-3

\begin{tabular}{|c|c|c|}
\hline Sr.No. & Mutants & $\begin{array}{c}\text { Protein } \mathrm{mg} / \mathrm{gm} \text { of defatted } \\
\text { seed powder }\end{array}$ \\
\hline 1 & Control & 67.65 \\
\hline 2 & Tall & 48.1 \\
\hline 3 & Dwarf & 39.37 \\
\hline 4 & Early maturing & 44.55 \\
\hline 5 & High yielding & 44.37 \\
\hline 6 & Late maturing & 36.3 \\
\hline 7 & Anthoseed & 24.3 \\
\hline 8 & Large leaf & 58.8 \\
\hline 9 & Elongate pod & 38.7 \\
\hline 10 & Early flowering & 26.55 \\
\hline
\end{tabular}

Table 3: Soluble protein content in different viable mutants of chickpea. Variety. PG-5

\begin{tabular}{|c|c|c|}
\hline Sr.No. & Mutants & $\begin{array}{c}\text { Protein } \mathrm{mg} / \mathrm{gm} \text { of defatted } \\
\text { seed powder }\end{array}$ \\
\hline 1 & Control & 58.17 \\
\hline 2 & Tall & 41.92 \\
\hline 3 & Dwarf & 31.12 \\
\hline 4 & Early maturing & 44.37 \\
\hline 5 & High yielding & 63.16 \\
\hline 6 & Late maturing & 66 \\
\hline 7 & Anthoseed & 27.1 \\
\hline 8 & Xantha & 28.12 \\
\hline 9 & Early flowering & 36.8 \\
\hline
\end{tabular}


Table 4: Seed protein content soluble in M3 micro mutants of chickpea

\begin{tabular}{|c|c|c|}
\hline Sr.No. & Micro mutants & Protein $\mathrm{mg} / \mathrm{gm}$ of defatted seed powder \\
\hline 1 & A1 & 54 \\
\hline 2 & A2 & 41.52 \\
\hline 3 & A3 & 60.64 \\
\hline 4 & B1 & 41.92 \\
\hline 5 & B2 & 35.96 \\
\hline 6 & B3 & 64.38 \\
\hline 7 & B4 & 58.65 \\
\hline 8 & B5 & 63 \\
\hline 9 & C1 & 44.37 \\
\hline 10 & C2 & 28.47 \\
\hline 11 & C3 & 31.12 \\
\hline 12 & C4 & 36.8 \\
\hline 13 & C5 & 26.67 \\
\hline 14 & E1 & 66.04 \\
\hline 15 & E2 & 37 \\
\hline 16 & F1 & 60.39 \\
\hline 17 & G1 & 63.16 \\
\hline 18 & G2 & 45.56 \\
\hline 19 & G3 & 66 \\
\hline 20 & G5 & 55.62 \\
\hline 21 & G6 & 27.1 \\
\hline 22 & H1 & 33.9 \\
\hline 23 & H3 & 50.75 \\
\hline 24 & H4 & 47.17 \\
\hline 25 & I2 & 44.27 \\
\hline & & \\
\hline
\end{tabular}

\section{Acknowledgement}

We are hearty thankful to Head Department of Botany Dr. Babasaheb Ambedkar Marathwada University Aurangabad, Maharashtra and Principal Vasant Mahavidyalaya Kaij, Dist: Beed to providing research field and laboratory facilities.

\section{References}

[1] Bhamburkar S. (1981): Experimental mutagenesis in black gram ( Vigna mungo L. Hepper). Ph.D. Thesis. Osmania University, Hyderabad.

[2] Blixt S (1967); Studies of induced mutations in peas XXIV genetically conditioned differences in radiation sensitivity-2, Herediatas, 59: 303- 326.

[3] Barshile JD and Apparao BJ (2009); Genetic improvement of chickpea (Cicer arientinum L.) using induced mutations, Q.Y.Shu (ed.) Induced Plant Mutation in the Genomic Era, Food and Agriculture organization of the United Nations, Rome, Pp. 101-104.

[4] Barshile JD, Auti SG and Apparao BJ (2009); Genetic enhancement of Chickpea through induced mutagenesis; J. Food Leg., 22 (1): 26-29.

[5] Borah SP and Goswami BC 1995. Induced high protein mutants with renewed Kernel P. Distribution and altered amino acid composition in rice. In: Proc. Symp. Genetic research and education: Current Trends and the next fifty years.New D. Vol III, PP 1239-1247.

[6] Chary SN (1983): Mutagenic studies in pigeonpea ( Cajanus cajan L. Millsp.) Ph.D. Thesis, Osmania University, Hyderabad.

[7] Dahiya B S (1973): Improvement of mung bean through induced mutations. Ind. J. Genet., 33: 460-468.
[8] Gottashalk W and Wolf G. (1983); Induced Mutations in Plant Breeding Monograph on Theoretical and Applied Genetics; Springer-Verlag, Berlin, Heidelberg, Pp. 323-327.

[9] Gottschalk W and Muller H. (1970); Monogenic Alterations of Seed protein content and protein pattern in X-ray induced Pisum mutants; in: "Improving Plant Protein by Nuclear Techniques." IAEA, Vienna, Pp: 201-215.

[10] Gottschalk W. and Muller HP 1982. Seed protein of Pisum mutants and recombinants. Qualitas Plantarum. 31: 296-306.

[11] Gottschalk W. and Wolff G. (1983): The behavior of protein rich pisum mutant in crossing experiments. In: Gottschalk W., Muller H. P. (Eds.) "Seed Protein, Biochemistry, Genetics, Nutritive value", Nishoff, The Hague: 403-425.

[12] Ignacimuthu S \& Babu C R 1989. Induced variation in protein quantity and quality in the wild and cultivated urd mungbeans. Indian. J. Genet. 49: 173-181.

[13] Jijiya BJ (1986): mutation breeding in phaseolus vulgaris L. Ph.D. thesis, Osmania University Hyderabad.

[14] Kalia C S, Kharakwal M C \& Singh M P 2000. Recovery of desirable mutations in wheat. Indian. $J$. Genet. 60(4): 465-470.

[15] Kharakwal MC (1998): Induced mutation for improvement of protein in chickpea ( cicer arietinum L.) Indian J.Genet. 58(1):61-69.

[16] Matta NK and Gatehouse JA 1982. Inheritance and mapping of storage protein genes in Pisum sativum L. Heredity. 48: 383-392.

[17] Naik BS, Parranayak SK and Kole C. (2002): selection of protein rich genotypes in mungbean ( vigna radiata. Wilezek L.) Ind. J. Genet. 60(3): 321-326.

[18] Narahari P. and Bhatia CR (1975): Breeding for seed protein improvement by using Molecular techniques. IAEA, Vienna: 23.

[19] Padmawati T. (1993): Mutagenic studies for the improvement of sunflower ( helianthus annuus) Ph.D. Thesis, Osmania univ. Hyderabad.

[20] Rayyan Asra (1995): mutagenesis and tissue culture studies in vigna mungo L. Hepper. Ph.D. Thesis, Osmania University, Hyderabad.

[21] Siddiq EA, Kaul AK, Puri RP, Singh VP and Swaminathan MS (1970): Mutagen induced variability in protein characters in Oryza sativa. Mut. Res., 10(1): 81-84.

[22] Singh RK (1996); Gamma rays induced bold seeded mutant in [Vigna mungo (L.) Hepper]; Indian J. Genet, 56: 104-108.

[23] Singh M. and Chaturvedi SN (1980): Effectiveness and efficiency of mutagens alone or in combination with dimethyl sulfoxide in Lathyrus. sativus L. Ind. J. Agri. Sci. 57(7): 503-507.

[24] Sjodin JJ (1971): Induced morphological variation in vicia faba L. Hereditas 67: 155-180.

[25] Sudharani T.(1990): Genetical studies in induced mutants of phaseolus mungo L. Ph.d. Thesis osmania uni. Hyderabad.

[26] Thakare RG and Pawar SE, Joshua DC, Mitra R. and Bhatia CR (1981): Variation in some physiological 


\section{International Journal of Science and Research (IJSR) \\ ISSN (Online): 2319-7064}

Index Copernicus Value (2013): 6.14 | Impact Factor (2014): 5.611

components of yield in induced mutants of mung bean. Proc., Int. symp. Vienna 9-13 March, IAEA, 213-226.

[27] Varughese G. and Swaminathan MS (1966): Changes

in protein quantity and quality associated with a mutation for amber color in wheat. Curr. Sci. 35:469470. 